\title{
11. 高脂血症診療の進歩
}

齋藤 康

Key words : 高脂血症, リポ蛋白, 動脈硬化, ガイドライン

はじめに

高脂血症が動脈硬化の危険因子であるという 多くの事実があり，最近の高脂血剂開発の進歩 により効果的な脂質低下剂が登場して高脂血症 の治療に上る動脈硬化性疾患の予防, 治療に関 する多くの治験が得られている，さらに治療対 象が 1,2 次予防, 男女, 老年者, あるいは合併 症を持つ例などいずれにおいても脂質低下療法 は動脈硬化の予防, 治療に有効であることを認 めることが確認され，日常診療においても大き な関心が寄せられるようになった。しかし高脂 血症の治療だけによる動脈硬化の予防, 治療へ の効果は必ずしも満足するレベルとはいいがた く，より効果を導くためにどのような方法を考 えていかねばならないかが問われているといえ る.そのためには高脂血症と動脈硬化の機序を 理解するとともに，その機序の是正を行うとい う視点が求められる.

\section{1. 高脂血症と高リポ蛋白血症について}

高脂血症は文字ど抒り血中に脂質成分が上昇 した状態を意味するわけであるが，多くの脂質 の種類のなかで臨床的に沉用されるのは総コレ

さいとう やすし：千葉大学大学院絸胞治療学
ステロールと中性脂肪である，両者ともにたか ければ高いほど動脈硬化の危険度をますという ことから, 高コレステロール血症は $220 \mathrm{mg} / \mathrm{dl}$, 高中性脂肪血症では $150 \mathrm{mg} / \mathrm{dl}$ 以上とすることが 日本動脈硬化学会ガイドラインには示されてい る1).このように脂質の量が高いというというこ とだけでは脂質の代謝を語るのには不十分であ ることも認識されている. 奏際血液を採取して 血清を観察すると高脂血症というなかにもこれ らの血中でのいろいろな存在様式即ちリポ蛋白 としての存在していることが血清の状態などで も理解できる。脂質と特異なタンパク質（アポ 蛋白）の複合体と示すことができる。これらの リポタンパクの意味を理解するためには、この リポタンパクの代謝を知ることは必須である(図 1).

リポタンパクの代謝は大きく分けて 3 つの経 路をとる. 一つはカイロミクロンの経路で, こ れは腸管から吸収された脂質主として中性脂肪 が血中に輸送されるもので，この中性脂肪は血 中でリポタンパクリパーゼ(LPL)によって代謝 され，その過程でHDL (high density lipoprotein) が生成される．さらに代謝物のカイロミクロン レムナントは肝臟に取り込まれる.VLDL (very ・ low-density lipoprotein）は肝臓から分泌され血 中ではTGが代謝されIDL (intermediate density lipoprotein)を生成する.この過程でもHDLが生 成される.IDLはさらに中性脂肪が肝性リパーゼ 


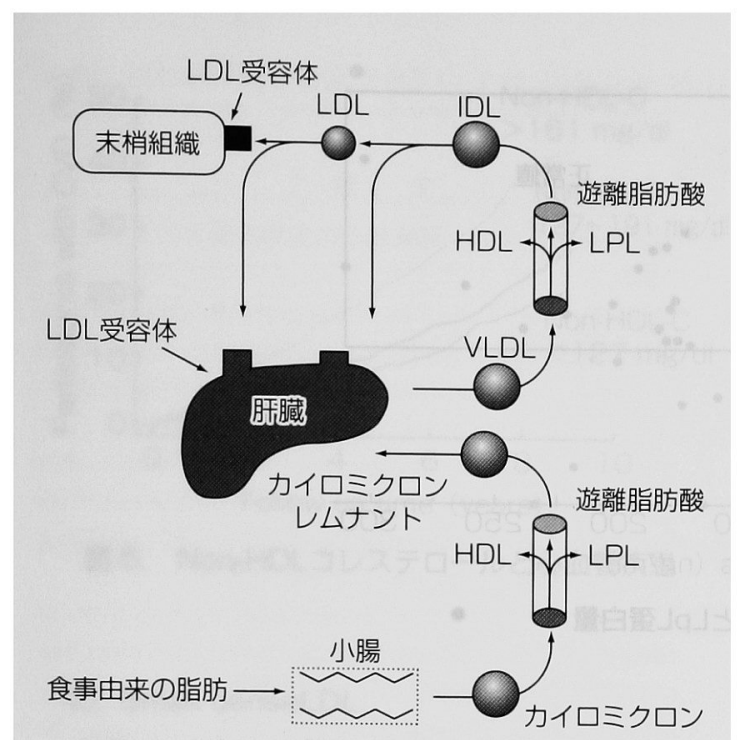

図 1.リポタンパク代謝

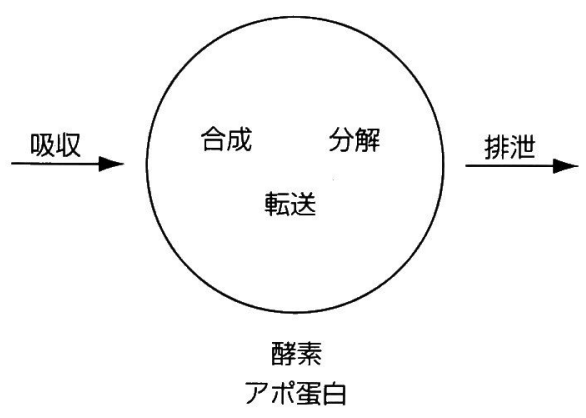

図 2. 高リポ蛋白血症の成り立ち

(HTGL)によって代謝されLDL (low density lipoprotein）を生成し，これは末梢の細胞に存在す るLDL受容体から細胞内に取り込まれる. HDL は末梢でLCAT (lecithin-cholesterol acyltransferase）の作用を介して余分のコレステロールを 抜き取り肝臓に転送するいわゆる逆転送を担っ ている．以上のようにリポタンパクは大きく分 けてカイロミクロン経路, VLDL-LDL経路, そ してHDL経路の 3 つがある.

従って高リポタンパク血症が生ずる機序には 図 2 に示すように，体外から脂質を摂取して吸 収して血中に入り，体内ではそれを材料として

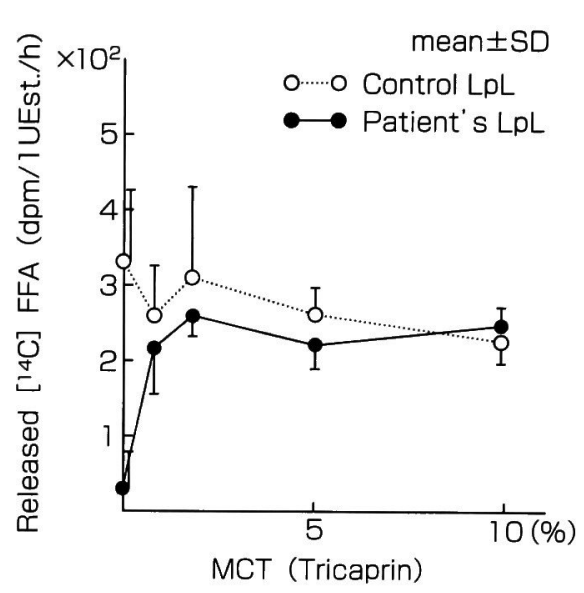

図 3. 基質にMCTを加えた時のLpL反応

さらに脂質を合成したり，分解したり，そして 転送をしたりという機序があり，それらが行わ れるためには酵素やアポ蛋白の機能が重要であ る. そして代謝産物は体外へ排泄されるのであ る.これら過程に何らかの障害が起こることに よって高リポタンパク血症は起こるのである.

\section{I 型高脂血症の成り立ちと治療一LPL 機能異常症}

I 型高脂血症の臨床症状の特徴は膵炎を伴う急 性腹症である.血清は白濁し, 放置するとクリー ム層といわれる所見が見られる.この原因はLPL の久損, もしくはその補酵素であるアポC-IIの久 損とされている．近年，高カイロミクロン血症 を呈しながら，アポC-IIは正常で,かつLPLの蛋 白量は正常という症例が報告されている2).この ような症例は従来の概念とは異なった解析が求 められそれは新しい治療が期待できるのである. この症例の場合, 酵素反応論で考える時, 基質 としてのカイロミクロンは存在し, 酵素として のLPLが存在しているのに反応が起こらないとい う解釈ができる。このような時に一つは阻害因 子の存在 ${ }^{3)}$ であり,もう一つは酵素の機能異常で ある.事実遺伝子解析によりC末端の二つのアミ 


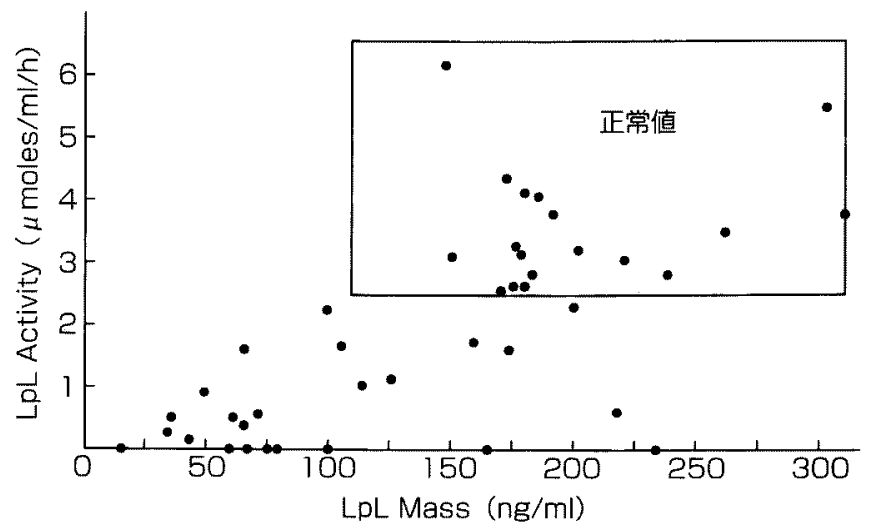

図 4. LpL活性とLpL蛋白量

ノ酸が久損していることが見られた.このcDNA から細胞でLPLを生成してこの䣼素の機能異常を 解析すると，このLPLはリポ蛋白へのaffinity がなくいわゆる基質一酵素複合体の形成に異常が ある酵素であると理解できる，この反応論につ いて，いろいろ基質の状態を変化させてこの異 常酵素の活性を検討した．脂質を分解する酔素 は一般に基質の状態によって活性を変化させる ことが知られている4). 図 3 に示すようにLPL の基質である長鎖脂肪酸を有する中性脂肪を中 鎖中性脂肪と混合して基質をつくると正常と同 じ活性を示すことが分かった.すなわちこのよ うな基質の状態をこの醉素は基質として認識で きることを示している，そこで実際にこの酵素 によって認識できるようなカイロミクロンをつ くれば分解が可能であることが推測できる，そ こでこのようなカイロミクロンを実際に体内に 作るために経口拱取できる中鎖中性脂肪を含む 溶液を作成して投与した，明らかに血中中性脂 肪が低下した.このような症例をLPL機能異常症 ということができる.従来のアポC-IIやLPL欠損 症と異なって日常で診断していくためには図 4 に示すように蛋白量があるにもかかわらず，活 性が低下している症例を見いだすことである。 しかしその症例にはいろいろな原因があること が推測され治療法についてはLPLの機能の解析が
求められる.

\section{3. 動脈硬化とリポタンパク}

リポ蛋白で動脈硬化を考える時, 動脈硬化学 会のガイドラインではいろいろな危険因子を考 慮した管理目標値を設定している1”。それは動脈 硬化がいろいろな危険因子を介して起こるとい うことを考慮した考えである。一方，リポ蛋白 にはその代謝過程でいろいろな中間体や化学的 修飾をうけたり，あるいはリポタンパク間の転 送によって，正常では見られないあるいはきわ めて微量なリポタンパクが異常に出現すること がある、それらのなかからいくつかについて紹 介军る。

\section{1) 酸化LDL}

動物塞験では動脈壁でその生成機序が明らか にされ，それを抑制することが動脈硬化を抑制 するという結果が示されてきた．しかし臨床的 に血中測定ができるようになり,血中の酸化LDL と動脈硬化の検討がなされている．酸化LDL の上昇は頸動脈の内膜中膜を促進すること5), ま た冠動脈疾患を有する例では血中酸化LDLが高 いことなどが示され゙，血中酸化LDLが動脈硬化 の危険因子として考えていくことが大切といえ る. 


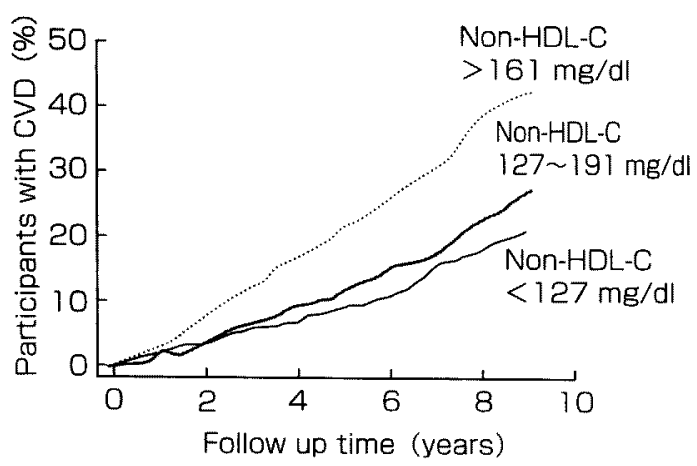

図 5. Non-HDLコレステロールと心血管疾患

\section{2) Small denseLDL}

正常のLDLに比較してサイズの小さいことが 電気泳動で容易にわかるものでこれが存在する 症例は冠動脈硬化の頻度が高いことが示されて いる6.これはこのLDLは正常のLDL受容体では なく，スカベンジャー受容体を介して取り込ま れ，泡沫化を促進することが明らかにされてい る.さらにこのsmall denseLDLは酸化されやす くこの経路を介した動脈硬化の危険因子として 役割を示しているのかもしれない5).

\section{3） Non-HDLコレステロール}

総コレステロールからHDLコレステロールを 引いた值として算出する。このなかにはきわめ て多彩なリポ蛋白が含まれており，どのように 解釈するかという点では異論のあるところであ るが，図 5 に示すように高いほど心血管疾患の 頻度が高いことが明らかにされている7. そして non-HDL-コレステロールの管理目標值として 2 次予防あるいはhigh risk群では 130 末満, 危険因 子二つを有する場合は 160 未满，そして危険因 子が 1 以下の場合は $190 \mathrm{mg} / \mathrm{dl}$ 未満を設定してい る.これらについては日本人において今後検討 される必要があろう。

4）その他

その他にもLP(a)やmidband, RLP (remmnant like particle) などの指標が用いられている。い ずれもりポタンパク代謝の産物であり，これら
を総合的に判断していくことが求められる.

\section{Metabolic syndromeという考え方}

WHOやATP II どのアメリカの機関からい くつかの危険因子が重なることがより重症な危 険因子になること，そしてそれらの危険因子が 同一の個体に重積するということを基準に診断 基準が提示されている 肪, HDLコレステロール，血圧，空腹時血糖な どをあげている．脂質から考える時にコレステ ロールは含まれていない. 従ってコレステロー ルとは明らかに異なったさらにそれぞれの危險 因子は比較的軽症であることに意味がある。そ もそも危険因子の考え方としていくつかの危険 因子はある一定以上の值を示す時にそれを異常 值として危険因子としているのである．単独で つよい危険因子となる時もある。その危険度は おおよそ正常の時の危険度を 1 とした時に 1.5 をこえるところにしていることが多く，その 1.5 をこえる危険因子の度合いを異常としているの である.しかし1から 1.5 の間にある時でも危険 度は明らかに正常よりは高いのであり，さらに いくつかの危険因子がこの範囲でも重なる時に は明らかに危険度を増すのである。従ってこの ような一つ一つは軽症であってもこれが同一個 体に起こる場合には治療の対象になるべきであ るという考えである。この発症機序には肥満と くに腹部肥満が関連することが示されており， 治療を考える上で重要なことである。

\section{5. 高脂血症の治療と効果判定の指標}

治療の方法は従来から行われてきた食事, 運 動, 薬物, LDLアフェレーシスである。脂質值 の改善を判定することは当然であるが近年の動 脈硬化の診断法の進歩により脂質低下療法の効 果について動脈硬化巣をみるという手法が行わ れている. 頸動脈雑音, 超音波やMRI (magnetic 
resonance imaging) あるいはCT (computed tomography)による頸動脈内膜中膜肥厚, 動脈䉾 の形状，石灰化などの変化について脂質低下療 法の効果として判定することが行われている。 さらに用いられている薬剤の多彩な作用も論じ られ,スタチンではpleiotropic effectとしてコレ ステロール低下とは違った細胞機能への作用と して基礎的のみならず，臨床的にもとらえられ ている9.ここれらの効果をあわせて観察していく ことが求められている。

今後の薬剤では腸管で作用する, EZETIMIBE，HDLを上昇させるCETPinhibitor, コレステロール低下薬MTPinhibitor, 泡沫 細胞形成抑制ACA Tinhibitor, HDLの機能賦活 剤としてETC588 などがあげられている.一部は 日本でも臨床開発が行われており今後が期待さ れる。

おわりに

高脂血症の診療はその診断法, 原因としての 遺伝子をはじめとした原因検索の進歩などによ り正確に行えるようになっている。ささらに目的 とする動脈硬化にあっては脂質低下療法の意義 が解明されるとともに，その効果を動脈硬化巣 でとらえるということが行われるようになって， より直接的に効果を判断していることになって いるといえよう．さらに動脈硬化の原因は多彩 な要因から起こるものでありそれらを総合した
診療が求められている.

\section{文献}

1）日本動脈硬化学会：動脈硬化性疾患診療ガイドライン. 2002.

2) Shirai $K$, et al : Type I hyperlipoproteinemia caused by lipoprotein lipase defect in lipid-interface recognition was relieved by administration of medium-chain triglyceride. Metabolism 41 (11) : 1161-1164, 1992.

3) Yanjuan Zhu, et al: Severe hypertriglyceridemia with plasma inhibitory factor(s) on lipoprotein lipase activity in a patient with a common Ser447-Ter LPL mutation. Clinica Chimica Acta 308: 139-146, 2001.

4) Shirai K, et al: Effects of phospholipids on hydrolysis of trioleoylglycerol by human serum carboxylesterase. Biochim Biophys Acta 962 : 377-383, 1988.

5) Tanaga $\mathrm{K}$, et al : Increased Circulating MalondialdehydeModified LDL Levels in Patients With Coronary Artery Diseases and Their Association With Peak Sizes of LDL Particles. Atherioscler Thromb Vasc Biol 22:662-666. 2002.

6) Lu W, et al : Non-HDL cholesterol as a predictor of cardiovascular disease in type 2 diabetes Diabetes Care $26: 16$ $23,2003$.

7) Anonymous : Executive summary of the Third Report of the National Cholesterol Education Program (NCEP) Expert Panel on Detection, Evaluation, and Treatment of High Blood Cholesterol in Adults (Adult Treatment Panel III). JAMA 285 (19) :2486-2497, 2001.

8) Executive Summary of the Third Report of the National Cholesterol Education Program (NCEP) expert panel on detection evaluation and treatment of high blood cholesterol in adults (Adult treatment panel III). JAMA 285: 2486, 2001.

9) International Task Force for Prevention of Coronary Heart Disease : Consensus on Statins, 2002 (prous science, Spain). 